\title{
THE PERCEPTION OF BUSINESS RISKS BY SMES IN THE CZECH REPUBLIC
}

\author{
Dvorský, J., Kozubíková, L., Bacová, B.
}

Ján Dvorský, L'udmila Kozubíková, Barbora Bacová / Tomas Bata University in Zlín, Faculty of Management and Economics, Department of Business Administration, Mostni 5139, 760 01, Zlín, Czech Republic.Email:j1dvorsky@utb.cz,kozubikova@utb.cz,b_bacova@utb.cz.

\section{Abstract}

This article aims to find out which business risks determine the perception of the business environment of small and medium-sized enterprises (SME) in the future. 454 SMEs from the Czech Republic participated in the case study by filling in an online questionnaire. Linear regression models were used to verify statistically significant causal relationships between selected indicators of business risks and respondents' perception of the future of business. The results show that selected indicators of the market, financial, personnel, legal and operational risk determine the perceived future of business. Strategic risk indicators do not significantly affect the perceived future of business. The most important indicators: market risk - adequacy of sales of products and services; financial risk - an indicator of the company's financial performance; personnel risk - an indicator of employees' initiative to increase performance; legal risk — an indicator of respondents' ability to understand the basic legal aspects and operational risk - an indicator of the use of company capacities. All the indicators from above have a positive effect on the future perception of the company.

Implications for Central European audience: The attitudes of small and medium-sized enterprises represent a certain degree of subjectivity (human factor), which does not always reflect the real position of the enterprise. However, it is the main representatives of SMEs (owners and top managers) who try to manage business risks to have a more positive perception of their future in the business environment in the Czech Republic. The results based on the business environment of the Czech Republic are important not only for the owners of SMEs, but also for state and non-profit institutions dealing with various forms of SME support.

Keywords: small and medium enterprises; future of business; business risks; Czech Republic

JEL Classification: M21, G32, L26

\section{Introduction}

Every conduct of business is always connected with a higher or lower degree of risk depending on many factors, external ones (development of macroeconomic indicators of a country as well as of the global economy) or internal ones (property and financial structure of an enterprise, qualification structure of employees, market areas, the management approach to risk, etc.). Such risks have an impact on small and medium-sized enterprises (SMEs), for 
which, as for their specifics and significance for the economies of the European Union (EU), including the Czech Republic, business risk management is crucial.

SMEs need to be helped to recognize the risks and then manage them afterwords. The diagnosis of key factors and determining the interactions of these factors in the risk management process of SMEs seem to be legitimate (Gorzeń-Mitka, 2019).

Business risk is a very complex issue as it includes more partial risks that are interconnected (Dvorský et al., 2019b; Dvorský et al., 2020; Kliestik et al., 2018). According to Fetisovová et al. (2012), business risks can be divided into strategic, operational, financial, social and political risks, and the risk of losing a company credit.

Havierniková and Kordoš (2019) focus on several aspects of risk classification: time aspect (strategic, operational), environmental aspect (external, internal), further breakdowns (financial, business, manufacturing, technological, exchange rate, political, social).

Shortcomings in risk identification and inadequate implementation of risk management can cause problems for SMEs in terms of competitiveness and sustainability. Sustainability has become crucial for SMEs, facing great pressure from large firms. The process of risk identification and risk analysis can be crucial for enterprises. Risks are no longer threats which should be avoided, but, in many cases, can be opportunities. Entrepreneurs must apply appropriate methods for risk management (Oláh et al., 2019).

Within risk management, an important part is the early identification of the company's future crisis in its initial symptoms. This proactive approach is often relatively problematic and feasible with a greater or lesser degree of probability. An analysis of various methods and models focusing on the corporate crisis shows that in most cases, they work and focus on financial factors and ignore the fact that in practice, management mistakes are a common cause of corporate crises, especially in the SME sector (Kurschus et al., 2015).

Corporate entity and personal entity conducting their business activities may find themselves in a situation where they are unable to meet their obligations. This condition is generally referred to by the foreign word insolvency, or in Czech bankruptcy. Given the important role that SMEs play in the performance of the Czech economy and the EU as a whole, the effort to analyze and understand the factors influencing their survival in more detail is important and justified.

The article contributes to the knowledge of different business risks and their influence on a firm's bankruptcy in the field of SMEs. The structure of the paper is as follows. Firstly, the literature review describes the SMEs environment and various business risks they face, concerning a firm's bankruptcy. Secondly, the aim and methodology are presented. Thirdly, the main results of the research are described and further discussed in the next part. The last part focuses on the conclusion, research limits and future directions.

\section{Literature review}

The important role of SMEs is confirmed by many authors (Ključnikov et al., 2017; Pisar \& Bilkova, 2019; Alnawas \& Farha, 2020; Lewandowska \& Stopa, 2018, 2019; Kraus et al., 2020; Lima et al., 2020). Due to their irreplaceable role, it is necessary to create favorable conditions for their business. Belás et al. (2019) found out that the most important influence 
in the formation of a QBE for SMEs are economic factors, the most important of which is the macroeconomic environment, followed by the monetary policy area and interest rates.

An important influence of macroeconomic conditions (e.g. the global financial crisis) and of various specific company characteristics (financial leverage and financial distress in a previous year, performance) on financial distress was revealed by Yazdanfar and Öhman (2020). The authors emphasize the advantage of the knowledge of firm financial condition because it can be used as a warning signal and basis for making better decisions before it is too late. Hence, it is understood before the firm's bankruptcy. They argue that financial distress models are ex-ante indicators of the probability of failure while bankruptcy models are based on the ex-post approach.

The conclusion from above made by Yazdanfar and Öhman (2020) is confirmed, for example, by Fernandez-Gamez et al. (2020) who emphasize that managing companies' financial risk using their economic and financial indicators only is not sufficient. In the context of globalized markets and internationalized companies, additional indicators related to the country in which a company operates must also be considered. It supports creating company profiles based on both their financial variables and each country's specific macroeconomic and regulatory factors.

Gorzen-Mitka (2019) states that risk management in the management of SMEs is an important challenge and it should be included in the decision-making process to meet their goals. Besides others, the authors focus on the factors influencing the implementation of Effective Risk Management (ERM) such as capital allocation methods, performance measurement mechanism, company size, level of institutional ownership, assets' opacity, growth opportunities. They consider risk communication as one of the crucial elements of ERM.

The results of Oláh et al. (2019) and Vu and Ngo (2019) indicate that personnel and operational risks are most present in the tourism sector. The analysis confirms that the agriculture industry is more exposed to operational risks than other services. This may indicate that in many types of jobs, people prefer to work in other sectors. For construction companies, legal and personnel risks are the most important forms of risk, while in the agricultural sector, operational and other business risks are crucial.

According to Kim and Vonortas (2014), operational risk covers dangers arising from the people, systems, and processes. It includes a superior term comprising legal risk, human, resource risk, fraud risk, etc. In comparison to Chaudhuri and Ghosh (2016), operational risk is defined as disaster risk, fraud risk, technological risk or litigation risk.

The strategic risks are those that may be an obstacle for the company in achieving its strategic goals. These risks arise from economic shifts and changes in the society, politics and environment (Chatterjee et al., 2003).

SMEs have specific characteristics that are considered to be their relative advantage. These are mainly specifics, such as a higher degree of flexibility and faster development in their strategies. On the other hand, they also struggle with certain limits, such as limited access to markets, a low degree of diversification and thus greater risk, due to limited access to external financing (Ključnikov et al., 2019). SMEs are therefore much more exposed to risk compared 
to large companies, and thus they should be interested in working with risks in terms of their prediction and management (Oláh et al., 2019; Lima et al., 2020).

According to Androniceanu (2017), most entrepreneurs try to identify risks, but they do not relate this activity to their business process to manage such risks. Prior studies showed that every entrepreneur has an interpretation and evaluation of the risk relevant to their risk management activities. It implies that the perception and ability to manage risks is influenced by the adopted approach to risk management.

Hudakova et al. (2018) emphasized the significance and importance of addressing the assessment of key risks and their sources in SMEs in Slovakia. The main results showed that market, financial, economic and personnel risks are considered to be the most important risks that negatively influence the business environment of SMEs. The entrepreneurs in the research perceived the dependence among the market factors, personnel risks, and business size. On the other hand, there was not found any dependence among the financial, economic and business risks. Based on the same results, Hudákova and Dvorský (2018) published that the most significant source of the market risk is a strong competition; of the economic risk, the main source is the development of the tax and insurance burden. As for the financial risk, insufficient company profit, unpaid receivables, inability to pay liabilities (insolvency) and indebtedness of the company is considered to be the most important sources.

Havierniková and Kordoš (2019) found out that the most important risk indicators are from the category of business risks and these indicators are related with the main issues of cluster cooperation: human factor failure, legal risk and risk related to the loss of own reputation. These results highlighted the importance of financial risks. Cluster cooperation and a new productive environment undoubtedly highlight the role of risk management.

Financial risk is one of the key threats to the activity of SMEs. The difficulty in financing the business and lack of funds is the most common aspect of the financial risk of SMEs. Overall, it can result in the rising operating costs, rising corporate debt, difficulty in debt repayment, and consequently, high financial risk (Korcsmáros \& Šimova, 2018). It was indicated that both the internationalization of the company and the ability to manage risk are the only factors that affect a high level of risk of low income (Ślusarczyk \& Grondys, 2019). The authors conclude that due to special characteristics of SMEs, the identification and measurement of SME financial risk should be different from the large ones.

The key findings of the Report on the Current State of Enterprise Risk Surveillance: Trends and Opportunities by the North Carolina State University's ERM Initiative together with the CPAs (US Certified Public Accountants) in the USA are as follows: lack of support for an early identification of risks; an inefficiently implemented risk management system in companies; increasing pressures from external control institutions to provide risk information; insufficient resources in companies to introduce a risk management system; delegating responsibility for risk control to internal audit and others (Enterprise Risk Management Initiative, 2017).

Business failure is connected with credit risk, which is one of the biggest risks of financial institutions. Therefore, there is pressure on financial institutions to still improve their credit risk management systems to predict bankruptcy as accurately as possible. The results showed that during the financial crisis, there are many factors influencing bankruptcy. On the other hand, during the upturn period, it is important to focus on earnings and assets whereas the importance of liabilities is not so high (Sponerová et al., 2019). The authors suggest that 
it is necessary to evaluate the financial information of the company regarding the period of economic development to assess the probability of bankruptcy precisely. As a result, a high proportion of external resources can lead to the bankruptcy of the company.

Insolvency is understood as a situation when a company is unable to meet its financial liabilities arising from business relationships, relationships with financial institutions, employees, and others on a specified date. The situation when the company has problems with the solvency because of the fact that its customers are not able to pay the accounts receivable on time, which causes a lower level of liquidity, and when the overdue receivables are becoming a subsequent reason why the company pays its accounts payable after the due date is called a secondary insolvency. The permanent insolvency of an enterprise can lead to firm's bankruptcy (Ključnikov et al., 2017; Kljucnikov et al., 2018).

Due to insolvency additional costs associated with the increased interest on loans, there is an increasing indebtedness, with penalty payments caused by delays in liabilities payments and others. It is also obvious that insolvency disrupts firm's reputation and discourages potential future partners (Kislingerová et al., 2010).

According to Ključnikov et al. (2017), it is necessary to choose business partners very carefully because one of the important factors influencing a company's ability or inability to pay liabilities is payment unwillingness (despite funds a company refuses or forgets to pay).

Kanapickiene and Spicas (2019) state that trade credit allows the supplier to increase sales and profits but creates the risk that the customer will not pay, and at the same time, this increases the risk of the supplier's insolvency. Regarding the fact that business credit is the most abundant form of credit, the authors try to avoid risks connected with trade credit by creating a statistical enterprise trade credit risk assessment (ETCRA) model for small and micro enterprises in Lithuania using financial (profitability, liquidity, solvency, activity) and non-financial variables.

The bankruptcy of a company is mainly related to financial risk, which can be defined from different points of view. Napp (2011) combines financial risk with external causes, such as changes in financial markets, and causes arising from the company's internal environment, such as financing risk, insolvency risk and liquidity risk. Pavelková and Knápková (2008) define financial risk as the additional variability of corporate earnings per share, resulting from the use of those forms of financing that force fixed payments, regardless of the development of the company's financial situation.

Belás et al. (2018) define financial risk as the probability that a company's financial performance will decline as a result of a variety of external and internal financial factors. It is, therefore, a comprehensive concept involving several basic groups, namely the risk of financing (the possibility that the company will not be able to finance its strategic objectives; the inability to obtain the required amount of funds at the time, own or external, especially credit) as well as credit risk (the possibility of inability or reluctance of the debtor to repay its liabilities - creditor risk), liquidity risk (a situation when the company will not have sufficient funds to repay its liabilities - debtor risk), and the interest rate risk and currency risk.

According to Ślusarczyk and Grondys (2019), any company, not only in the SME sector, should deal with the task of managing financial risk in the manner that will bring greater benefits to it. Based on the authors' opinions, an important part of the financial risk of SMEs 
is a higher share of foreign capital in their financing. A low share of equity limits the sovereignty of SMEs and can lead to difficulties in daily short-term business operations.

The European Commission (2014) considers insolvency to be a normal situation that often occurs in a dynamic modern economy. Related to its data, approximately half of all enterprises survive less than five years and almost 200,000 enterprises in the EU face insolvency each year (it implies that insolvency influences about 600 companies in Europe daily).

The study of Gupta et al. (2018) suggests that survival (failure) probability increases (decreases) with increasing firm size. Firms in different size categories have varying determinants of bankruptcy. However, the factors affecting the financial distress of SMEs are mostly invariant. The authors assume that the principal source of external funding for SMEs is debt, and more specifically, bank lending. Nevertheless, lenders face problems with forecasting loan performance. Inadequately measured credit risk can generate damaging impacts for SMEs.

Kljucnikov et al. (2018) revealed that the company size and the owner's gender do have an impact on the ability to pay accounts payable on time. The regression analysis discovered the existence of the statistically significant linear relationship between the solvency problems of SMEs and the payment discipline of their customers in Slovakia. It was also found that the secondary insolvency is a serious problem of SMEs in comparison with the primary one. The problems with the defaulters or late-paying customers and business partners sufficiently influence the liquidity of SMEs.

Cathcart et al. (2020) showed that financial leverage has a greater impact on the default probability of SMEs than it has on the large ones. The difference in default probability between the top and bottom leverage quartiles is $1.24 \%$ for large firms and $2.87 \%$ for SMEs. The authors explained the difference by the greater exposure of SMEs to short-term debts and, consequently, their higher refinancing risk. It was also found that the liability structure of SMEs is significantly altered towards long-term debts and away from short-term debts.

Kang et al. (2019) suggest that, for the reason of a more severe asymmetric information problem, SMEs have a higher credit risk than larger firms. It means that the credit risk affects a set of financial activities in general and even more so in SMEs. The results of their research showed that in SMEs with low credit risk, the debt ratio is negatively related to firm performance. However, in SMEs with high credit risk, this relationship is not present. It follows that SME credit risk moderates the relationship between capital structure and firm performance.

Lukason et al. (2019) investigated how reporting timeliness is linked with bankruptcy risk and its determinants (liquidity, profitability and leverage) in Estonia. Their findings showed that higher bankruptcy risk increased, but in turn, high liquidity, annual profitability and accumulated profitability decreased the likelihood of delayed reporting. These results point to the fact that healthy companies are more willing to disclose their official financial information on time.

Based on Schwab et al. (2019), the risk of failure in growing firms is significant during the period of growth. Financial managers of growing firms should be aware of the fact that 
allowing their customers to pay with large delays (more than 30 days) dramatically increases the risk of bankruptcy.

Susi and Lukason (2019) studied other factors linked to failure risk. The authors found out that with the manager's higher age and the presence of managerial ownership, failure risk reduces. On the other hand, the presence of larger boards and managers having directorships in other firms leads to a higher failure risk. The factors such as gender heterogeneity in the board, board tenure length and ownership concentration are not associated with failure risk.

\section{Aim, methodology and data}

The article aims to find out which business risks determine the perception of the future of business in the business environment of small and medium-sized enterprises in the Czech Republic. The data were collected in the period from 09/2019 to 04/2020. The statistical unit is characterized as an entrepreneur (owner or senior manager) of a small or medium-sized enterprise (SME), which operates in the business environment of the Czech Republic (hereinafter referred to as the "respondent"). The CRIBIS database was used to define the basic set of respondents and then to address them. The opinions of respondents were obtained by the method of questioning in the form of filling in an online questionnaire or printed form of the questionnaire. In the first phase, respondents were contacted via an email with a structured request to complete the online questionnaire "Management, business risks and bankruptcies in the segment of small and medium-sized enterprises in the Czech Republic". In the second phase, the companies were contacted by telephone with a request to complete the questionnaire. ${ }^{1}$

The questionnaire consisted of 77 questions divided into several parts. In the first part of the questionnaire, we found out the basic characteristics of the respondent and the company (questions no. 1-10). The second part (questions no. 11-34) of the questionnaire contained statements concerning management, corporate social responsibility, marketing, social media and internationalization of business. The third part (questions no. 35-67) of the questionnaire contained allegations concerning business risks, namely strategic, market, financial, personnel, legal and operational risks. The fourth part (questions no. 62-67) of the questionnaire examined the respondent's attitudes towards the claims regarding the bankruptcy of the company. The fifth part (questions no. 68-77) of the questionnaire focused on the causes of the company's bankruptcy and risk management. The statements were formulated into statements to which the respondents could react in one of the following ways: (A1) strongly agree, (A2) agree, (A3) neither agree nor disagree, (A4) disagree, (A5) strongly disagree.

The number of correctly completed questionnaires (hereinafter referred to as the "sample") represented $454(97.6 \%)$ respondents. The number of incorrectly completed questionnaires represented $11(2.4 \%)$ respondents. The most important reasons for excluding a respondent from the sample are as follows: duplication of the questionnaire in the sample; consistency of the respondent's approach to the assessment of business risks; the respondent's

\footnotetext{
${ }^{1}$ The questionnaire is still available on the Internet at https://forms.gle/okjZypAru4BpSHFb8
} 
inattention when answering the questions which the respondent did not have to answer, etc. The allegations of business risks and bankruptcy were formulated positively to maintain the continuity of responses. To meet the main goal of the article, the following statements about business risks and the emotional future of the company were formulated:

\section{Strategic risk statements}

SR1: Strategic management in a company is an integral part of corporate governance. SR2: Strategic management is implemented in the everyday life of our company and done through action plans and programs. SR3: Proper strategic management improves the competitive ability of our company and its stability in domestic and foreign markets. SR4: Our company regularly monitors, evaluates and manages strategic risks.

\section{Market risk statements (MR)}

MR1: I rate the market risk (lack of sales for my company) as adequate. MR2: Business competition motivates me to perform better. MR3: Selling products and services on the market is challenging. However, our company has adequate sales volume. MR4: Our company uses innovative ways to win new markets and retain existing customers.

\section{Financial risk statements (FR)}

FR1: I consider financial risk as part of everyday business. FR2: I evaluate the financial performance of our (my) company positively. FR3: I understand the most crucial aspect of financial risk. FR4: I can adequately manage the financial risk in my (our) company.

\section{Personnel risk statements (PER)}

PER1: Personnel risk in the company is considered adequate and does not harm my business. PER2: Employee turnover is low and has no negative impact on my business. PER3: The error rate of employees is low and has no negative impact on my (our) business. PER4: Our employees strive to improve their performance and competition among them prevails.

\section{Legal risk statements (LEG)}

LEG1: I consider the legal risk appropriate and does not harm our (my) business. LEG2: Business is affected by frequent legislative changes, but it has no negative impact on our (my) business. LEG3: I do not consider the business environment to be 'over-regulated'. LEG4: I understand the essential legal aspects of doing business.

\section{Operational risk statements (OPE)}

OPE1: We use company capacities at a sufficient level. OPE2: We place great emphasis on the innovation of our products and services, and it is positively reflected in the stability and performance of the company. OPE3: The number of possible requests for specific products/services has a downward trend. OPE4: Our company is not dependent on a limited number of suppliers. 


\section{Perception of the future of business (Y)}

There is no risk of bankruptcy for our (my) company within 5 years.

The authors formulated the scientific hypothesis of research as follows:

$\mathrm{H}$ : The selected business risk (Ha: Strategic risk $\left(\mathrm{H}_{\mathrm{a}, \mathrm{SR} 1} ; \mathrm{H}_{\mathrm{a}, \mathrm{SR} 2} ; \mathrm{H}_{\mathrm{a}, \mathrm{SR} 3} ; \mathrm{H}_{\mathrm{a}, \mathrm{SR} 4}\right)$, Hb: Market risk $\left(H_{b, M R 1} ; H_{b, M R 2} ; H_{b, M R 3} ; H_{b, M R 4}\right)$, Hc: Financial risk $\left(H_{c, F R 1} ; H_{c, F R 2} ; H_{c, F R 3} ; H_{c, F R 4}\right), H d$ : Personnel risk ( $\mathrm{H}_{\mathrm{d}, \mathrm{PER} 1}$; $\left.\mathrm{H}_{\mathrm{d}, \mathrm{PER} 2} ; \mathrm{H}_{\mathrm{d}, \mathrm{PER} 3} ; \mathrm{H}_{\mathrm{d}, \mathrm{PER} 4}\right)$, He: Legal risk $\left(\mathrm{H}_{\mathrm{e}, \mathrm{LEG} 1} ; \mathrm{H}_{\mathrm{e}, \mathrm{LEG} 2} ; \mathrm{H}_{\mathrm{e}, \mathrm{LEG} 3}\right.$; $\left.\mathrm{H}_{\mathrm{e}, \mathrm{LEG} 4}\right)$, Hf: Operational risk $\left(\mathrm{H}_{\mathrm{f}, \mathrm{OPE} 1} ; \mathrm{H}_{\mathrm{f}, \mathrm{OPE} 2} ; \mathrm{H}_{\mathrm{f}, \mathrm{OPE} 3} ; \mathrm{H}_{\mathrm{f}, \mathrm{OPE} 4)}\right)$ has a positive impact on the perception of the future of business in the entrepreneurial environment of small and mediumsized enterprises in the Czech Republic.

Applying regression analysis in many scientific studies as a means of predicting a dependent variable in the future (Nava et al., 2018). Applying regression analysis may not always be the primary main. Regression analysis can also be used to identify and quantify independent variables (selected business risks) and to determine the direction and strength of the impact on a dependent variable. This second way of using regression analysis is also important and used in practice (Civelek et. al, 2019; Dvorský et al., 2019a). Due to the fact that all examined variables (independent, dependent) are identical metrics (same scaling of responses), it is possible to use this statistical method to evaluate the formulated hypothesis.

To apply regression analysis, the assumptions about independent variables must be met. The independent variables must satisfy the assumptions of linearity; normal distribution and homoskedasticity. Also, the regression model must not be affected by multicollinearity. Also, the assumptions about the random component of the regression model must be met (Goodman, 1970). The assumption of linearity was verified by graphical analysis of the data using a scatter plot (de Waal, 1977; Hair et al., 2010). The assumption of a normal distribution of respondents' attitudes (for individual claims on business risks) was verified by calculating and testing descriptive characteristics (skewness and kurtosis). If the value of skewness and kurtosis were in the range of -2 to 2 , then the assumption of a normal distribution is accepted (James, 1964). A correlation matrix with pairwise correlation coefficients was used to determine the relationship between the dependent variable and the independent variables. The correlation coefficient $(R)$ can take values in the range from - 1 to 1 (Lancaster \& Hamdan, 1964; Hair et al., 2010). Student's t-test is applied to verify the significance of regression coefficients of independent variables. The regression coefficient in the regression model is statistically significant if the p-value of the t-test is lower than the level of significance (Qin \& Lawless, 1995; Zheng \& Yu, 2015). The general linear regression model has the following form:

$$
Y=\beta_{0}+\beta_{1} \times S R_{1}+\beta_{2} \times S R_{2}+\beta_{3} \times S R_{3}+\beta 4 \times S R_{4}+\varepsilon_{n}
$$

where $Y$ - independent variable (perception of the future of business); $\beta_{0}-$ intercept, $\beta_{1} ; \ldots ; \beta_{4}-$ regression coefficients of independent variables; $S R_{1}, \ldots, S R_{4}$ - independent variables $(i=1, \ldots, 4-$ strategic risk statements); $\varepsilon_{n}$ - random error. Analogously, it is possible to create LRM for other types of business risks (RM2: MR, ..., RM6: OPE). 
We verify the quality of the regression model by calculating and interpreting regression characteristics such as multiple correlation coefficient (MCC), determination coefficient $\left(\mathrm{R}^{2}\right)$, adjusted determination coefficient (Adj. $R^{2}$ ), F-ratio, multicollinearity, normality of errors (Breslow, 1990). The coefficient of determination indicates the percentage of explanation of variability of the perception of the future of the business, which can be explained by the selected independent variables (Lancaster \& Hamdan, 1964). The F-test was used to verify the statistical significance of the regression model (de Waal, 1977). The required $p$-value of the F-test must be lower than the level of significance, then the regression model is statistically significant. The assumption of multicollinearity is verified in the regression model by using the variation factor of inflation (VIF - test) (Liao et al., 2012). If the value of the VIF test for the independent variable is lower than 5 , then this coefficient is not affected by multicollinearity (Arnold, 1980; Salmerón et al., 2018). The Shapiro-Wilk test (S-W test) was applied to verify the normal distribution of errors (de Waal, 1977). This assumption of the regression model is accepted when the $p$-value of the test criterion of the S-W test is higher than the level of significance. The Bartlett test was used to verify the assumption of homoscedasticity. This assumption is accepted if the p-value of the Bartlett test criterion is higher than the level of significance (Arnold, 1980; Snedecor \& Cochran, 1989).

Basic evaluation of questions according to the characteristics of a company/respondents: size of an enterprise: 107 (23.6\%) small enterprise (10-49 employees), 290 (63.9\%) micro enterprise (less than or equal to 10 employees), 57 (12.5\%) medium enterprise (between 50 to 249 employees); type of an entity: 135 sole trader $(29.7 \%), 266(58.6 \%)$ limited liability company, 34 (7.5\%) joint-stock company, 19 (4.2\%) another form of business; how long have you been doing business: $27(5.9 \%)$ less than or equal to 3 years, $28(6.2 \%)$ more than 3 and less than or equal to 5 years, $64(14.1 \%)$ more than 5 and less than or equal to 10 years, $335(73.8 \%)$ more than 10 years; the highest level of education: $46(10.1 \%)$ Comprehensive college, 185 (40.8\%) High school graduate, 34 (7.5\%) Bachelor's degree, 168 (37.0\%) Master's degree, 21 (4.6\%) Doctoral degree; gender of a respondent: 323 men $(71.1 \%), 131$ (28.9\%) women; age of a respondent: $69(15.2 \%)$ less than 35 years old, $106(23.3 \%)$ from 36 to 45,122 (26.9\%) from 46 to 55, 157 (34.6\%) more than 56; relationships between the education of a respondent and the area of business: 171 (37.7\%) Yes, I do business in the area of my education, 158 (34.8\%) Somewhat related (some business processes are related to the area of my education), $125(27.5 \%)$ unrelated; position of a respondent in the company: $354(22.0 \%)$ I am the business owner; 100 (78.0\%) I am a manager.

\section{Results}

The basic descriptive statistics (DS) of indicators of entrepreneurial risk (mean (M), standard deviation (SD), skewness (S) and kurtosis (K)) are show in Table 1. 
Table 1 | Selected descriptive characteristics of the evaluation of business risk indicators

\begin{tabular}{|c|c|c|c|c|c|c|c|c|}
\hline \multirow{2}{*}{ DS } & \multicolumn{4}{|c|}{ STRATEGIC RISK } & \multicolumn{4}{|c|}{ MARKET RISK } \\
\hline & SR1 & SR2 & SR3 & SR4 & MR1 & MR2 & MR3 & MR4 \\
\hline M & 1.802 & 2.542 & 2.194 & 2.707 & 2.458 & 2.035 & 2.260 & 2.564 \\
\hline SD & 0.825 & 1.072 & 0.991 & 1.174 & 1.022 & 1.009 & 0.941 & 1.085 \\
\hline S & 1.421 & -0.301 & -0.070 & 2.014 & 0.114 & 0.599 & 0.190 & -0.524 \\
\hline $\mathbf{K}$ & 1.046 & 0.398 & 0.601 & 2.147 & 0.625 & 0.977 & 0.657 & 0.340 \\
\hline \multirow{2}{*}{ DS } & \multicolumn{4}{|c|}{ FINANCIAL RISK } & \multicolumn{4}{|c|}{ PERSONNEL RISK } \\
\hline & FR1 & FR2 & FR3 & FR4 & PER1 & PER2 & PER3 & PER4 \\
\hline M & 1.938 & 2.231 & 1.965 & 2.121 & 2.678 & 2.430 & 2.348 & 2.744 \\
\hline SD & 0.965 & 0.989 & 0.891 & 0.907 & 1.140 & 1.244 & 1.109 & 1.155 \\
\hline $\mathbf{S}$ & 2.312 & 0.406 & 0.644 & 0.627 & -0.587 & -0.679 & -0.259 & -0.692 \\
\hline $\mathbf{K}$ & 2.077 & 0.776 & 0.841 & 0.741 & 0.448 & 0.559 & 0.675 & 0.277 \\
\hline \multirow{2}{*}{ DS } & \multicolumn{4}{|c|}{ LEGAL RISK } & \multicolumn{4}{|c|}{ OPERATIONAL RISK } \\
\hline & LEG1 & LEG2 & LEG3 & LEG4 & OPE1 & OPE2 & OPE3 & OPE4 \\
\hline $\mathbf{M}$ & 2.773 & 2.954 & 3.370 & 1.870 & 2.077 & 2.198 & 1.731 & 2.357 \\
\hline SD & 1.109 & 1.282 & 1.295 & 0.832 & 0.843 & 0.986 & 0.875 & 1.304 \\
\hline $\mathbf{S}$ & -0.549 & -1.015 & -0.950 & 0.775 & 0.397 & -0.106 & 1.324 & -0.883 \\
\hline $\mathbf{K}$ & 0.419 & 0.150 & -0.358 & 0.849 & 0.673 & 0.594 & 1.185 & 0.565 \\
\hline
\end{tabular}

Source: own calculation

The assumption of a normal distribution is fulfilled for each independent variable, without SR4 and FR1 (see Table 1). For these variables, the value is not in the range of -2 to 2 (SR4: Skewness $=2.014$; Kurtosis $=2.147$; FR1: Skewness $=2.312 ;$ Kurtosis $=2.077$ ). Due to a sufficiently large sample size ( $n=454$; Hair et al., 2010), the assumption of a normal distribution for the variables FR1 and SR4 is accepted.

The following Table 2 summarizes the pairwise correlation coefficients in the correlation matrices between the independent variables and perception of the future of business $(\mathrm{Y})$.

Table 2 | Dependence of indicators of business risk and dependent variable

\begin{tabular}{llllllllllll}
\hline SR & Y & SR1 & SR2 & SR3 & SR4 & MR & Y & MR1 & MR2 & MR3 & MR4 \\
\hline Y & 1 & & & & & Y & 1 & & & & \\
SR1 & 0.056 & 1 & & & & MR1 & 0.309 & 1 & & & \\
SR2 & 0.134 & 0.544 & 1 & & & MR2 & 0.151 & 0.205 & 1 & & \\
SR3 & 0.074 & 0.506 & 0.593 & 1 & & MR3 & 0.239 & 0.340 & 0.318 & 1 & \\
SR4 & 0.112 & 0.437 & 0.597 & 0.504 & 1 & MR4 & 0.095 & 0.173 & 0.238 & 0.211 & 1 \\
\hline FR & $\mathbf{Y}$ & FR1 & FR2 & FR3 & FR4 & PER & Y & PER1 & PER2 & PER3 & PER4 \\
\hline Y & 1 & & & & & Y & 1 & & & & \\
FR1 & 0.021 & 1 & & & & PER1 & 0.143 & 1 & & & \\
FR2 & 0.380 & 0.133 & 1 & & & PER2 & 0.169 & 0.519 & 1 & & \\
FR3 & 0.193 & 0.236 & 0.345 & 1 & & PER3 & 0.168 & 0.413 & 0.627 & 1 \\
FR4 & 0.198 & 0.145 & 0.410 & 0.708 & 1 & PER4 & 0.203 & 0.340 & 0.413 & 0.473 & 1 \\
\hline
\end{tabular}




\begin{tabular}{llllllllllll}
\hline LEG & $\mathbf{Y}$ & LEG1 & LEG2 & LEG3 & LEG4 & OPE & $\mathbf{Y}$ & OPE1 & OPE2 & OPE3 & OPE4 \\
\hline $\mathbf{Y}$ & 1 & & & & & $\mathbf{Y}$ & 1 & & & & \\
LEG1 & 0.190 & 1 & & & & OPE1 & 0.295 & 1 & & & \\
LEG2 & 0.131 & 0.430 & 1 & & & OPE2 & 0.190 & 0.372 & 1 & & \\
LEG3 & 0.144 & 0.284 & 0.235 & 1 & & OPE3 & 0.255 & 0.321 & 0.284 & 1 & \\
LEG4 & 0.178 & 0.167 & 0.148 & 0.092 & 1 & OPE4 & 0.222 & 0.196 & 0.242 & 0.249 & 1 \\
\hline
\end{tabular}

Source: own calculation

The following Tables 3, 4 and 5 summarize the results of verification of the statistical significance of the proposed regression models (RM1, ..., RM6).

Table 3 | The impact of indicators of the strategic and market risk on the perception of the future

\begin{tabular}{|c|c|c|c|c|c|c|c|c|c|}
\hline \multicolumn{5}{|c|}{ RM1 - Impact SR on Y } & \multicolumn{5}{|c|}{ RM2 - Impact MR on Y } \\
\hline MCC & \multicolumn{2}{|c|}{0.140} & Adj. $R$ & 0.015 & MCC & 0.345 & \multicolumn{2}{|c|}{ Adj. $R^{2}$} & 0.111 \\
\hline $\mathbf{R}^{2}$ & \multicolumn{2}{|c|}{0.020} & SE & 1.108 & $\mathbf{R}^{2}$ & 0.119 & \multicolumn{2}{|c|}{ SE } & 1.052 \\
\hline \multicolumn{5}{|c|}{ Verification of the significance of LRM } & \multicolumn{5}{|c|}{ Verification of the significance of LRM } \\
\hline ANOVA & Df. & ss & MS & F- ratio & ANOVA & Df. & SS & MS & F- ratio \\
\hline Reg. & 2 & 11.016 & 5.508 & 4.490 & Reg. & 4 & 67.030 & 16.757 & 15.131 \\
\hline Residual & 451 & 553.292 & 1.227 & $P$ - value & Residual & 449 & 497.278 & 1.108 & $P$ - value \\
\hline Total & 453 & 564.308 & & 0.012 & Total & 453 & 564.308 & & 1.3E-11 \\
\hline
\end{tabular}

\begin{tabular}{llllllllllllll}
\hline \multicolumn{2}{l}{ Statistical significance testing } & \multicolumn{1}{l}{ Statistical significance testing } \\
\hline Variables & RC & SE & t-Stat & $\begin{array}{l}\text { Sign. } \\
\text { (p-val.) }\end{array}$ & VIF & Variables & RC & SE & t-Stat & $\begin{array}{l}\text { Sign. } \\
\text { (p-val.) }\end{array}$ & VIF \\
\hline Intercept & 1.834 & 0.146 & 12.574 & 0.000 & - & Intercept & 1.054 & 0.181 & 5.841 & 0.000 & - \\
SR2 & 0.158 & 0.060 & 2.633 & 0.025 & - & MR1 & 0.273 & 0.052 & 5.255 & 0.000 & 1.155 \\
& & & & & & MR2 & 0.060 & 0.053 & 1.146 & 0.252 & 1.160 \\
SR4 & 0.128 & 0.055 & 2.327 & 0.045 & - & MR3 & 0.160 & 0.058 & 2.740 & 0.006 & 1.235 \\
& & & & & & & MR4 & 0.011 & 0.048 & 0.224 & 0.823 & 1.092
\end{tabular}

Note: Df. - Degree of freedom; SS - Sum of Squares; MS - Mean square; SE - Standard Error; RC Regression Coefficient; VIF - Variance Influence Factor.

Source: own calculation

The results (see Table 3) show that the proposed regression model of the linear relationships between the perception of the future of business and the indicators of strategic risk is statistically significant $(\mathrm{RM} 1$ : F-ratio: $p$-value $=0.012)$. The strategic risk indicators $(\mathrm{SR} 2$ and SR4) do have a statistically significant effect on the dependent variable ( $t-S t a t: p$-value is less than the level of significance). The results of the RM2 model show that the relationship between the dependent variable and the market risk indicators is statistically significant ( $\mathrm{F}$ ratio: $p$-value $=1.3 \mathrm{E}-11)$. The market risk indicators (MR2 and MR3) do have a statistically significant effect on the dependent variable (MR1: $p$-value $=0.000 ;$ MR3: $p$-value $=0.006$ ). The form of the regression functions is:

$$
Y=1.834+0.158 \times S R 1+0.128 \times S R 4+\varepsilon_{t},
$$


where $Y$ - dependent variable (perception of the future of business); SR1 and SR4 - independent variables (indicators of the strategic risk); $\varepsilon_{t}$ - random error.

$$
Y=1.054+0.273 \times M R 1+0.060 \times M R 2+0.160 \times M R 3+0.011 \times M R 4+\varepsilon_{t},
$$

where $Y$ - dependent variable (perception of the future of business); MR1,.., MR4 - independent variables (indicators of the market risk); $\varepsilon_{t}$ - random error.

The VIF test values did not show the presence of multicollinearity in the regression model (see Table 3). Homoscedasticity was confirmed for both regression models (RM1: Bartlett's test: $p$-value $=0.211 ;$ RM2: Bartlett's test: $p$-value $=0.297$ ). The normal distribution of errors was confirmed for both regression models by S-W test (RM1: $S-W$ test: $p-v a l u e=0.473$; RM2: S-W test: $p$-value $=0.355)$. The evaluation of scientific hypothesis: $\mathrm{H}_{\mathrm{a}, \mathrm{SR} 1}, \mathrm{H}_{\mathrm{a}, \mathrm{SR} 3}$,

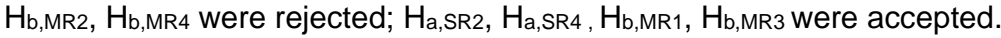

Table 4 | The impact of indicators of the financial and personnel risk on the perception of the future

\begin{tabular}{|c|c|c|c|c|c|c|c|c|c|c|c|}
\hline \multicolumn{6}{|c|}{ RM3 - Impact FR on Y } & \multicolumn{6}{|c|}{ RM4 - Impact PER on Y } \\
\hline MCC & \multicolumn{2}{|l|}{0.396} & Adj. $R^{2}$ & \multicolumn{2}{|l|}{0.149} & MCC & \multicolumn{2}{|c|}{0.224} & Adj. $\mathbf{R}^{2}$ & \multicolumn{2}{|l|}{0.046} \\
\hline $\mathbf{R}^{2}$ & \multicolumn{2}{|l|}{0.157} & SE & \multicolumn{2}{|l|}{1.030} & $\mathbf{R}^{2}$ & \multicolumn{2}{|c|}{0.050} & SE & \multicolumn{2}{|l|}{1.090} \\
\hline \multicolumn{6}{|c|}{ Verification of the significance of LRM } & \multicolumn{6}{|c|}{ Verification of the significance of LRM } \\
\hline ANOVA & Df. & ss & MS & \multicolumn{2}{|l|}{ F- ratio } & ANOVA & Df. & ss & PMS & \multicolumn{2}{|l|}{ F- ratio } \\
\hline Regression & 4 & 88.317 & 22.079 & \multicolumn{2}{|l|}{20.827} & Regression & 2 & 28.259 & 14.130 & \multicolumn{2}{|l|}{11.888} \\
\hline Residual & 449 & 475.991 & 1.060 & \multicolumn{2}{|c|}{$P$ - value } & Residual & 451 & 536.049 & 1.189 & \multicolumn{2}{|c|}{$P$ - value } \\
\hline Total & 453 & \multicolumn{2}{|l|}{564.308} & \multicolumn{2}{|l|}{$9.2 \mathrm{E}-16$} & Total & 453 & \multicolumn{2}{|l|}{564.308} & \multicolumn{2}{|l|}{$6.3 \mathrm{E}-06$} \\
\hline \multicolumn{6}{|c|}{ Statistical significance testing } & \multicolumn{6}{|c|}{ Statistical significance testing } \\
\hline Variables & $\mathbf{R C}$ & SE & t-Stat & $\begin{array}{l}\text { Sign. } \\
\text { (p-val.) }\end{array}$ & VIF & Variables & RC & SE & t-Stat & $\begin{array}{l}\text { Sign. } \\
\text { (p-val.) }\end{array}$ & VIF \\
\hline Intercept & 1.310 & 0.161 & 8.119 & 0.000 & - & Intercept & 1.587 & 0.143 & 11.109 & 0.000 & - \\
\hline FR1 & 0.104 & 0.052 & 2.019 & 0.044 & 1.064 & \multirow{2}{*}{ PER2 } & \multirow{2}{*}{0.093} & \multirow{2}{*}{0.045} & \multirow{2}{*}{2.048} & \multirow{2}{*}{0.041} & \multirow{2}{*}{$\begin{array}{ll}- \\
-\end{array}$} \\
\hline FR2 & 0.408 & 0.054 & 7.559 & 0.000 & 1.217 & & & & & & \\
\hline FR3 & 0.112 & 0.079 & 1.421 & 0.156 & 2.092 & \multirow{2}{*}{ PER4 } & \multirow{2}{*}{0.155} & \multirow{2}{*}{0.049} & 3184 & (1) & - \\
\hline FR4 & 0.000 & 0.078 & 0.006 & 0.995 & 2.144 & & & & & & \\
\hline
\end{tabular}

Note: Df. - Degree of freedom; SS - Sum of Squares; MS - Mean square; SE - Standard Error; RC Regression Coefficient; VIF - Variance Influence Factor.

Source: own calculation

The results (see Table 4) show that the proposed regression model of the linear relationships between the perception of the future of business and the indicators of financial risk (RM3) and personnel risk (RM4) are statistically significant (RM3: F-ratio: $p$-value = 9.2E-16; RM4: F-ratio: $p$-value $=6.3 \mathrm{E}-06)$. The form of the regression functions is:

$$
Y=1.310+0.104 \times F R 1+0.408 \times F R 2+0.112 \times F R 3+0.000 \times F R 4+\varepsilon_{t,}
$$

where $Y$ - dependent variable (perception of the future of business); FR1,..., FR4 - independent variables (indicators of the financial risk); $\varepsilon_{t}-$ random error. 


$$
Y=1.587+0.093 \times P E R 2+0.155 \times P E R 4+\varepsilon_{t},
$$

where $Y$ - dependent variable (perception of the future of business); PER2, PER4 - independent variables (indicators of the personnel risk); $\varepsilon_{t}$ - random error.

The VIF test values did not show the presence of multicollinearity in the regression model (see Table 4). Homoscedasticity was confirmed for both regression models (RM3: Bartlett's test: $p$-value $=0.259 ;$ RM4: Bartlett's test: $p$-value $=0.383$ ). The normal distribution of errors was confirmed for both regression models by S-W test (RM3: S-W test: $p-v a l u e=0.118$; RM4: S-W test: $p-v a l u e=0.641$ ). The evaluation of scientific hypothesis: $H_{c, F R 3, ~} H_{c, F R 4}$, $\mathrm{H}_{\mathrm{d}, \mathrm{PER} 1}, \mathrm{H}_{\mathrm{d}, \mathrm{PER} 3}$ were rejected; $\mathrm{H}_{\mathrm{c}, \mathrm{FR} 1}, \mathrm{H}_{\mathrm{c}, \mathrm{FR} 2}, \mathrm{H}_{\mathrm{d}, \mathrm{PER} 2}, \mathrm{H}_{\mathrm{d}, \mathrm{PER} 4}$ were accepted.

Table 5 | The impact of indicators of the legal and operational risk on the perception of the future

\begin{tabular}{|c|c|c|c|c|c|c|c|c|c|c|c|}
\hline \multicolumn{6}{|c|}{ RM5 - Impact LEG on Y } & \multicolumn{6}{|c|}{ RM6 - Impact OPE on Y } \\
\hline MCC & \multicolumn{2}{|l|}{0.256} & Adj. $R^{2}$ & \multicolumn{2}{|l|}{0.059} & MCC & \multicolumn{2}{|c|}{0.368} & Adj. $R^{2}$ & \multicolumn{2}{|l|}{0.128} \\
\hline $\mathbf{R}^{2}$ & \multicolumn{2}{|l|}{0.066} & SE & \multicolumn{2}{|l|}{1.082} & $\mathbf{R}^{2}$ & \multicolumn{2}{|c|}{0.136} & SE & \multicolumn{2}{|l|}{1.042} \\
\hline \multicolumn{6}{|c|}{ Verification of the significance of LRM } & \multicolumn{6}{|c|}{ Verification of the significance of LRM } \\
\hline ANOVA & Df. & ss & MS & \multicolumn{2}{|l|}{ F- ratio } & ANOVA & Df. & ss & PMS & \multicolumn{2}{|l|}{ F- ratio } \\
\hline Regression & 3 & 37.081 & 12.360 & \multicolumn{2}{|l|}{10.550} & Regression & 4 & 76.466 & 19.117 & \multicolumn{2}{|l|}{17.594} \\
\hline Residual & 450 & 527.227 & 1.172 & \multicolumn{2}{|l|}{$P$ - value } & Residual & 449 & 487.842 & 1.087 & \multicolumn{2}{|l|}{$P$ - value } \\
\hline Total & 453 & \multicolumn{2}{|l|}{564.308} & \multicolumn{2}{|l|}{$1.02 \mathrm{E}-06$} & Total & 453 & 564.308 & & \multicolumn{2}{|l|}{$2.0 \mathrm{E}-13$} \\
\hline \multicolumn{6}{|c|}{ Statistical significance testing } & \multicolumn{6}{|c|}{ Statistical significance testing } \\
\hline Variables & RC & SE & t-Stat & $\begin{array}{l}\text { Sign. } \\
\text { (p-val.) }\end{array}$ & VIF & Variables & $\mathrm{RC}$ & SE & t-Stat & $\begin{array}{l}\text { Sign. } \\
\text { (p-val.) }\end{array}$ & VIF \\
\hline Intercept & 1.217 & 0.192 & 6.337 & 0.000 & - & Intercept & 0.979 & 0.162 & 6.031 & 0.000 & - \\
\hline \multirow{2}{*}{ LEG1 } & \multirow{2}{*}{0.141} & \multirow{2}{*}{0.048} & \multirow{2}{*}{2.907} & \multirow{2}{*}{0.004} & \multirow{2}{*}{1.111} & OPE1 & 0.274 & 0.065 & 4.245 & 0.000 & 1.238 \\
\hline & & & & & & OPE2 & 0.044 & 0.055 & 0.796 & 0.427 & 1.233 \\
\hline LEG3 & 0.078 & 0.041 & 1.900 & 0.048 & 1.090 & OPE3 & 0.183 & 0.061 & 3.004 & 0.003 & 1.189 \\
\hline LEG4 & 0.197 & 0.062 & 3.175 & 0.002 & 1.032 & OPE4 & 0.117 & 0.040 & 2.952 & 0.003 & 1.110 \\
\hline
\end{tabular}

Note: Df. - Degree of freedom; SS - Sum of Squares; MS - Mean square; SE - Standard Error; RC Regression Coefficient; VIF - Variance Influence Factor.

Source: own calculation

The results (see Table 5) show that the proposed regression model of the linear relationships between the perception of the future of business and the indicators of legal risk (RM5) and operational risk $(R M 6)$ are statistically significant (RM5: F-ratio: $p$-value $=1.02 E-06$; RM6: $F$ ratio: $p$-value $=2.0 \mathrm{E}-13)$. The form of the regression functions is:

$$
Y=1.217+0.141 \times L E G 1+0.078 \times L E G 3+0.197 \times L E G 4+\varepsilon_{t},
$$

where $Y$ - dependent variable (perception of the future of business); LEG1,..., LEG4 - independent variables (indicators of the legal risk); $\varepsilon_{t}$ - random error.

$$
Y=0.979+0.274 \times O P E 1+0.044 \times O P E 2+0.183 \times O P E 3+0.117 \times O P E 4+\varepsilon_{t},
$$


where $Y$ - dependent variable (perception of the future of business); OPE1,..., OPE4 - independent variables (indicators of the operational risk); $\varepsilon_{t}-$ random error.

The VIF test values did not show the presence of multicollinearity in the regression model (see Table 5). Homoscedasticity was confirmed for both regression models (RM5: Bartlett's test: $p$-value $=0.187$; RM6: Bartlett's test: $p$-value $=0.207)$. The normal distribution of errors was confirmed for both regression models by S-W test (RM5: $S-W$ test: $p$-value $=0.084$; RM6: $S-W$ test: $p$-value $=0.132$ ). The evaluation of scientific hypothesis: $H_{e, L E G 2, ~} H_{f, O P E 2}$ were rejected; $\mathrm{H}_{\mathrm{e}, \mathrm{LEG} 1}, \mathrm{H}_{\mathrm{e}, \mathrm{LEG} 3}, \mathrm{H}_{\mathrm{e}, \mathrm{LEG} 4}, \mathrm{H}_{\mathrm{f}, \mathrm{OPE} 1}, \mathrm{H}_{\mathrm{f}, \mathrm{OPE} 3}, \mathrm{H}_{\mathrm{f}, \mathrm{OPE} 4}$ were accepted.

\section{Discussion}

The ability of enterprises to maintain a sufficient degree of competitiveness in today's globalized environment requires a consistent management approach and maximum alignment of all organizational activities and actors involved in the performance management process (Labudova \& Janosova, 2019).

Efficient risk management in SMEs significantly determines their survival in the market and contributes to the development of not only the company itself but also its market and social environment. At the same time, it is necessary to realize that appropriate risk management requires the awareness, identification, planning, and prevention of numerous threats from these companies. But in SMEs, the management process, as opposed to larger companies, is often neglected, which also contributes to the emergence of numerous threats (Ślusarczyk \& Grondys, 2019).

On one hand, the risks related to the perception of the company existence in the future are threatening. On the other hand, these can be understood as future opportunities in terms of increasing profits, improving corporate performance, gaining new markets, expanding the company's portfolio, etc. (Oláh et al., 2019). Labudova \& Janosova (2019) confirmed in their research the idea that the most important success factor in business is risk taking.

The main results in the individual risk areas can be summarized as follows. The perception of the company's future is influenced by the implementation of strategic management in the everyday life of the company $(p$-value $=0.025)$ and the fact that the company regularly monitors, evaluates, and manages strategic risks (SR4: $p$-value $=0.045)$. The most important indicator of strategic risk, having the greatest positive impact on the future of business, is the implementation of strategic management in the everyday life of the company $(\beta=0.158)$.

The perception of the company's future is influenced by the assessment of primary sales of services and products $(\mathrm{MR} 1$ : $\mathrm{p}$-value $=0.000)$ and the fact that the company has a reasonable difficulty in selling products and services (MR3: $p$-value $=0.006$ ). The most important indicator of market risk, having the greatest positive impact on the future of business, is the assessment of adequate sales of services and products $(\beta=0.273)$. The positive impact of the difficulty in selling products and services $(\beta=0.160)$ is also significant. The positive impact of competition as a motivating factor for the respondents and the company's ability to gain new markets in innovative ways were not confirmed (MR2: $p$-value $=0.252$ and MR4: $p$-value $=0.823$ ).

The perception of the future of the company is influenced by the perception of financial risk as a part of everyday life (FR1: $p$-value $=0.044$ ) and a positive perception of the financial 
performance of the company (FR2: $p$-value $=0.000$ ). The most significant indicator of financial risk, having the greatest impact on the future of business, is a positive perception of the financial performance of the business $(\beta=0.408)$. The impact of the respondents' ability to understand the most important aspects of financial risk and the respondents' ability to properly manage financial risk were not confirmed (FR3 - p-value $=0.156$ and FR4: $p$-value $=0.995)$.

The perception of the future of the company is positively influenced by the employees' efforts to increase performance $(\beta=0.155)$ and by the influence of employee turnover $(\beta=0.093)$. The employees' efforts to increase performance is a stronger indicator than employee turnover. The error rate of employees and the adequacy of personnel risk and its impact on business in the future of the company were not confirmed.

The perception of the future of the entrepreneurship is positively influenced by the adequacy of legal risk in the business environment (LEG1: $p$-value $=0.004$ ), by the respondent's opinion that the business environment is over-regulated (LEG3: $p$-value $=0.048$ ) and by the respondents' ability to understand the basic legal aspects of the business (LEG4: $p$-value = $0.002)$. The ability of respondents to understand the basic legal aspects of the business $(\beta=$ 0.197 ) is the most significant indicator of a legal risk. The impact of frequent legislative changes (t-test: LEG2 - $p$-value $=0.427$ ) is not significant for the future of business.

The perception of the future of business is influenced by all indicators of operational risk (the usability of company capacities, a low number of complaints made by customers and the independence of the company from a limited number of suppliers) except for the impact of innovation of products and services in the stability and performance of the enterprise (OPE2: $p$-value $=0.427)$. The usability of company capacities $(\beta=0.274)$ has the most significant positive impact on the future of business.

\section{Conclusion}

The article aimed to identify business risks that affect the perception of the future of business in the business environment of small and medium-sized enterprises in the Czech Republic. The results show that selected indicators of the market, financial, personnel, legal and operational risk determine the perceived future of business. The strategic risk indicators do not significantly affect the perceived future of business. The most important indicators: market risk - adequacy of sales of products and services; financial risk - an indicator of the company's financial performance; personnel risk - an indicator of employee's initiative to increase performance; legal risk - an indicator of the respondent's ability to understand the basic legal aspects and operational risk - an indicator of the use of company capacities.

Despite the authors' efforts to obtain the largest possible sample of business entities $(n=454)$ from the business environment of the Czech Republic, this fact can be considered limiting. On the other hand, the methodological part of the article describes in detail the structure of the respondents. Another limit is the local nature of research.

We strive to compare our findings regarding the impact of business risks on the perception of the future of SMEs in the Czech Republic with other countries of the Visegrad Group (V4). Therefore, we are currently starting to work with academic staff from partner universities in Hungary, Poland and the Slovak Republic in order to obtain a relevant sample of 
respondents. At the same time, in the Czech Republic, we will again address SMEs with a request to complete a questionnaire for re-verification of models and examine the differences arising from the current COVID-19 pandemic.

\section{Acknowledgement}

Publication of this paper was supported by The Internal Grant Agency No. IGA/FAME2019/001 Key Factors Determining the Business Performance of Small and Medium-Sized Enterprises for the FaME, Tomas Bata University in Zlín.

\section{References}

Alnawas, I., \& Abu Farha, A. (2020). Strategic orientations and capabilities' effect on SMEs' performance. Marketing Intelligence \& Planning, 38(7), 829-845. https://doi.org/10.1108/MIP-11-2019-0548

Androniceanu, A. (2017). The three-dimensional approach of total quality management, an essential strategic option for business excellence. Amfiteatru Econ, 19(44), 61-67.

Arnold, S.F. (1980). Asymptotic validity of $F$ tests for the ordinary linear model and the multiple correlation model. Journal of the American Statistical Association, 75(372), 890-894. https://doi.org/10.1080/01621459.1980.10477568

Belás, J., Gavurová, B., \& Virglerová, Z. (2018). Podniková ekonomika III - Řizení a ekonomika podniku. Zlín: Univerzita Tomáše Bati ve Zlíně.

Bodlaj, M., \& Cater, B. (2019). The impact of environmental turbulence on the perceived importance of innovation and innovativeness in SMEs. Journal of Small Business Management, 57, 417-435. https://doi.org/10.1111/jsbm.12482

Breslow, N. (1990). Tests of hypotheses in overdispersed poisson regression and other quasi-likelihood models. Journal of the American Statistical Association, 85(410), 565-571. https://doi.org/10.1080/01621459.1990.10476236

Cathcart, L., Dufour, A., Rossi, L., \& Varotto, S. (2020). The differential impact of leverage on the default risk on small and large firms. Journal of Corporate Finance, 60. https://doi.org/10.1016/j.jcorpfin.2019.101541

Civelek, M., Ključnikov, A., Krajčík, V., \& Žufan, J. (2019). The importance of discount rate and trustfulness of a local currency for the development of local tourism. Journal of Tourism and Services, 10(19), 77-92. https://doi.org/10.29036/jots.v10i19.117

Dvorský, J., Petraková, Z., Çera, G., \& Folvarčná, A. (2019a). Important factors for the entrepreneurship in central Europe. Innovative Marketing, 15(2), 71-83. https://doi.org/10.21511/im.15(2).2019.06

Dvorský, J., Petráková, Z., \& Polách, J. (2019b). Assessing the market, financial, and economic risk sources by Czech and Slovak SMEs. International Journal of Entrepreneurial Knowledge, 7(2), 30-40. https://doi.org/10.12345-0008

Dvorský, J., Petráková, Z., \& Fialová, V. (2020). Perception of business risks by entrepreneurs according to experience with the business failure. International Journal of Entrepreneurial Knowledge, 8(1), 76-88. https://doi.org/10.37335 / ijek.v8i1.104

Enterprise Risk Management Initiative (2017). 2015 Report on the current state of enterprise risk management: Update on trends and opportunities [online]. Retrieved from http://erm.ncsu.edu/library/article/current-state-erm-2015 
European Commission (2014). Platobná neschopnost': Komisia odporúča nový prístup s ciel'om zachránit' podniky a dat' poctivým podnikatel'om druhú šancu [press release]. Retrieved from http:/europa.eu/rapid/press-release_IP-14-254_sk.html

Fernandez-Gamez, M.A., Soria, J.A.C., Santos, J.A.C., \& Alaminos, D. (2020). European country heterogenity in financial distress prediction: An empirical analysis with macroeconomic and $\begin{array}{llll}\text { regulatory factors. Economic Modelling, 398-407. } & \text { 88, }\end{array}$ https://doi.org/10.1016/j.econmod.2019.09.050

Fetisovová et al. (2012). Aktuálne problémy financií malých a stredných podnikov. Bratislava: Ekonóm.

Goodman, L.A. (1970). The multivariate analysis of qualitative data: Interactions among multiple classifications. Journal of the American Statistical Association, 65(329), 226-256. https://doi.org/10.1080/01621459.1970.10481076

Gorzeń-Mitka, I. (2019). Interpretive structural modeling approach to analyze the interaction among key factors of risk management process in SMEs: Polish experience. European Journal of Sustainable Development, 8(1), 339-349. https://doi.org/10.14207/ejsd.2019.v8n1p339

Gupta, J., Barzotto, M., \& Khorasgani, A. (2018). Does size matter in predicting SMEs failure? International Journal of Finance \& Economics, 23(4), 571-605. https://doi.org/10.1002/ijfe.1638.

Hair, J.F., Anderson, R.E., Babin, B.J., \& Black, W.C. (2010). Multivariate data analysis: A global perspective (7th ed.). Upper Saddle River, NJ: Pearson Prentice Hall.

Havierniková, K., \& Kordoš, M. (2019). The SMEs'perception of financial risks in the context of cluster cooperation. Quantitative Finance and Economics, 3(3), 586-607. https://doi.org/10.3934/QFE.2019.3.586

Hudakova, M., Masar, M., Luskova, M., \& Patak, M.R. (2018). The dependence of perceived business risks on the size of SMEs. Journal of Competitiveness, 10(4), 54-69. https://doi.org/10.7441/joc.2018.04.04

Hudáková, M., \& Dvorský, J. (2018). Assessing the risks and their sources in dependence on the rate of implementing the risk management process in the SMEs. Equilibrium. Quarterly Economic Journal and Economic Policy, 13(3), 543-567. https://doi.org/10.24136/eq.2018.027

Chatterjee, S., Wiseman, R.M., Fiegenbaum, A., \& Devers, C.E. (2003). Integrating behavioural and economic concepts of risk into strategic management: The twain shall meet. Long Range Planning, 36(1), 61-79. https://doi.org/10.1016/S0024-6301(02)00201-7

Chaudhuri, A., \& Ghosh, S.K. (2016). Quantitative modeling of operational risk in finance and banking using possibility theory. Studies in Fuzziness and Soft Computing 331, https://doi.org/10.1007/978-3-319-26039-6

James, A.T. (1964). Distribution of matrix variates and latent roots derived from normal samples. The Annals of Mathematical Statistics, 35(2), 475-501. https://doi.org/10.1214/aoms/1177703550

Kanapickiene, R., \& Spicas, R. (2019). Credit risk assessment model for small and micro-enterprises: The case of Lithuania. Risks, 7(2), 67. https://doi.org/10.3390/risks7020067

Kang, L., Niskanen, J., \& Niskanen, M. (2019). Capital structure and firm performance in European SMEs. Does credit risk make a difference? Managerial Finance, 45(5), 582-601. https://doi.org/10.1108/MF-01-2017-0018

Kim, Y., \& Vonortas, N.S. (2014). Managing risk in the formative years: Evidence from young enterprises in Europe. Technovation, 34(8), 454-465. https://doi.org/10.1016/j.technovation.2014.05.004

Kislingerová, E. et al. (2010). Manažerské finance. C.H. Beck. 
Kliestik, T., Vrbka, J., \& Rowland, Z. (2018). Bankruptcy prediction in Visegrad group countries using multiple discriminant analysis. Equilibrium. Quarterly Journal of Economics and Economic Policy, 13(3), 569-593. https://doi.org/10.24136/eq.2018.028

Ključnikov, A., Kozubíková, L., \& Sopková, G. (2017). The Payment Discipline of Small and Mediumsized Enterprises. Journal of Competitiveness, 9(2), 45-61. https://doi.org/10.7441/joc.2017.02.04

Ključnikov, A., Sobekova-Majkova, M., Vincurova, Z., \& Sarvutyte-Gailiuniene, M. (2018). The insolvency of SMEs within the perspective of the central European region. Transformations in Business \& Economics, 17(2), 210-224.

Ključnikov, A., Civelek, M., Čech, P., \& Kloudová, J. (2019). Entrepreneurial orientation of SMEs' executives in the comparative perspective for Czechia and Turkey. Oeconomia Copernicana, 10(4), 773-795. https://doi.org/10.24136/oc.2019.035

Korcsmáros, E., \& Šimova, M. (2018). Factors affecting the business environment of SMEs in Nitra region in Slovakia. Oeconomia Copernicana, 9(2), 309-331. https://doi.org/10.24136/oc.2018.016.

Kraus, S., Kailer, N., Dorfer, J., \& Jones, P. (2020). Open innovation in (young) SMEs. International Journal of Entrepreneurship and Innovation, 21(1), 47-59. https://doi.org/10.1177/1465750319840778

Kurschus, R.-J., Sarapovas, T., \& Cvilikas, A. (2015). The criteria to identify company's crisis in SME sector. Engineering Economics, 26(2), 152-158. https://doi.org/10.5755/j01.ee.26.2.8779

Labudova, L., \& Janosova, D. (2019). Analysis of support and identification of barriers to SMEs in Slovakia and in the Czech Republic. Serbian Journal of Management, 14(2), 437-453. https://doi.org/10.5937/sjm14-23494

Lancaster, H.O., \& Hamdan, M.A. (1964). Estimation of the correlation coefficient in contingency tables with possibly nonmetrical characters. Psychometrica, 29, 383-391. https://doi.org/10.1007/BF02289604

Lewandowska, A., \& Stopa, M. (2018). SMEs innovativeness and institutional support system: The local experiences in qualitative perspective. Polish case study. Oeconomia Copernicana, 9(2), 333351. https://doi.org/10.24136/oc.2018.017

Lewandowska, A., \& Stopa, M. (2019). Do SME's innovation strategies influence their effectiveness of innovation? Some evidence from the case of Podkarpackie as peripheral region in Poland. Equilibrium. Quarterly Journal of Economics and Economic Policy, 14(3), 521-536. https://doi.org/10.24136/eq.2019.025

Lima, P.F.D., Crema, M., \& Verbano, C. (2020). Risk management in SMEs: A systematic literature review and future directions. European Management Journal, 38(1), 78-94. https://doi.org/10.1016/j.emj.2019.06.005

Lukason, O., \& Camacho-Minano, M.D.M. (2019). Bankruptcy risk, its financial determinants and reporting delays: Do managers have anything to hide? Risks, 7(3), 77. https://doi.org/10.3390/risks7030077

Napp, A.K. (2011). Financial risk management in SME. The use of financial analysis for identifying, analysing and monitoring internal financial risk [master thesis]. Retrieved from http://pure.au.dk/portal-asb-student/files/39817962/Thesis_A Napp.pdf

Nava, N., Di Matteo, T., \& Aste, T. (2018). Financial time series forecasting using empirical mode decomposition and support vector regression. Risks, 6(1), 1-21. https://doi.org/10.3390/risks6010007 
Oláh, J., Virglerova, Z., Popp, J., Kliestikova, J., \& Kovács, S. (2019). The assessment of non-financial risk sources of SMEs in the V4 countries and Serbia. Sustainability, 11(17), 4806. https://doi.org/10.3390/su11174806

Pavelková, D., \& Knápková, A. (2008). Podnikové finance. Zlín: Univerzita Tomáše Bati.

Pisar, P., \& Bilkova, D. (2019). Controlling as a tool for SME management with an emphasis on innovations in the context of Industry 4.0. Equilibrium. Quarterly Journal of Economics and Economic Policy, 14(4), 763-785. https://doi.org/10.24136/eq.2019.035

Qin, J., \& Lawless, J. (1995). Estimating equations, empirical likelihood and constraints on parameters. Canadian Journal of Statistics, 23(2), 145-159. https://doi.org/10.2307/3315441

Schwab, L., Gold, S., \& Reiner, G. (2019). Exploring financial sustainability of SMEs during periods of production growth: A simulation study. International Journal of Production Economics, 212(June), 8-18. https://doi.org/10.1016/j.ijpe.2018.12.023

Ślusarczyk, B., \& Grondys, K. (2019). Parametric conditions of high financial risk in the SME sector. Risks, 7(3), 84. https://doi.org/10.3390/risks7030084

Snedecor, G.W., \& Cochran, W.G. (1989). Statistical Methods (8th ed). lowa State University Press.

Sponerová, M., Svoboda, M., \& Sponer, M. (2019). Prediction of bankruptcy in a different period of economic development. European Financial Systems 2019. Proceedings of the 16th International Scientific Conference (pp. 554-559). Brno: Masaryk University.

Susi, V., \& Lukason, O. (2019). Corporate governance and failure risk: Evidence from Estonian SME population. Management Research Review, 42(6), 703-720. https://doi.org/10.1108/MRR-032018-0105

Vu, H.M, \& Ngo, V.M. (2019). Strategy development from triangulated viewpoints for a fast growing destination toward sustainable tourism development - A case of Phu Quoc Islands in Vietnam. Journal of Tourism and Services, 10(18), 117-140. https://doi.org/10.29036/jots.v10i18.86

de Waal, D.J. (1977). Asymptotic distributions for the elementary symmetric functions of two matrices under the assumption of linearity. Journal of Multivariate Analysis, 7(1), 223-228. https://doi.org/10.1016/0047-259X(77)90042-2

Yazdanfar, D., \& Öhman, P. (2020). Financial distress determinants among SMEs: Empirical evidence from Sweden. Journal of Economic Studies, 47(3), 547-560. https://doi.org/10.1108/JES-012019-0030

Zheng, M., \& Yu, W. (2015). Linear regression analysis with inequality constraints on the regression parameters via empirical likelihood. Journal of Statistical Computation and Simulation, 85(9), 1782-1792. https://doi.org/10.1080/00949655.2014.902459

The research paper passed the review process. | Received: June 6, 2020; Revised: June 30, 2020;

Accepted: July 2, 2020; Published: December 21, 2020. 